\title{
Textural and compositional variation of sand along the Manahara-Bagmati river basin, Kathmandu Valley
}

\author{
Naresh Kazi Tamrakar and Hari Nandan Gurmaita \\ Central Department of Geology, Tribhuvan University, Kirtipur, Kathmandu
}

\begin{abstract}
The Manahara-Bagmati river basin is located in a humid climate and has a $51 \mathrm{~km}$ long low gradient profile. It collects sediments from metamorphic, metasedimentary, and fluvio-lacustrine sources. The sediment samples collected from 17 localities were studied texturally and compositionally to infer how sediment modifies due course of transport and whether the trends are interfered by mixing, recycling, and weathering. For this purpose, two size grades (i.e., $0-1 \phi$ and $2-3 \phi$ ) were studied. Between them, the trends were more conspicuous in the $0-1 \phi$ sand grade. Mean $\left(\mathrm{M}_{z}\right)$ and median $\left(\mathrm{M}_{\mathrm{d}}\right)$ grain sizes increase downstream exponentially. Sorting $\left(\sigma_{1}\right)$ also improves along the river course. Quartz content gradually increases downstream, whilst feldspars and rock fragments decrease remarkably along the river course. Rapid dilution of feldspars and rock fragments (from coarser size grade) occurs after $27 \mathrm{~km}$ of transport. The Modified Maturity Index, which ranges from 19.8 to 214 , increases from the Manahara to Bagmati River sands. The mica content in the Bagmati River is from 2 to
8 times higher than in the Manahara River.

Within the studied river course, the mean projection sphericity $\left(\Psi_{\mathrm{p}}\right)$ of quartz remains high $(0.80$ in average $)$ but does not show any consistent trend. The mean roundness $(\rho)$ of the $0-1 \phi$ sand grade increases conspicuously against the distance of transport. The majority of samples belong to submature class. Local influx of sediments and recycling are profound from Sankhu to Sanothimi and from Chobhar to Hasdol. Rapid weathering of labile grains is inferred in the middle reach of the Manahara-Bagmati river system (i.e., between Sanothimi and Chobhar).
\end{abstract}

\section{INTRODUCTION}

In the process of fluvial transport, the sediment undergoes compositional and textural modifications. While the initial composition and texture of the sediment may depend on the source rock and tectonics (Ingersoll an Suczek 1979; Dickinson et al. 1986; McBride and Picard 1987; Girty and Armitage 1989; Johnson 1990) from which it is liberated, the river transport may also modify both the composition and texture depending on topographic, climatic and weathering conditions (Breyer and Bart 1976; Suttner and Dutta 1986; Grantham and Velbel 1988), extent of abrasion, and sorting (Slingarland 1984), and scale of recycling (Cavazza et al. 1993; Cox and Lowe 1995).

The segment of the river under investigation exhibits a low gradient and is fed by the tributaries originated from metamorphic as well as metasedimentary provinces. The Manahara and Bagmati Rivers themselves flow through the fluvio-lacustrine sediments of the Kathmandu Valley. Thus, these rivers may possess sediments from various sources. However, the abundance of particular mineral grains and rock fragments may depend on their durability. Under these circumstances, the composition and texture of sediments may depend on their transport history and the type of source rock. Our main objectives here were to find out (a) how the texture and composition of sediment are modified by a lowgradient river transport, and (b) whether these modifications are supplemented by recycling, mixing, and weathering.
The Manahara-Bagmati river basin is located in the humid climate of warm temperate zone. The annual means of maximum and minimum temperatures are 24.4 and $12.5^{\circ} \mathrm{C}$, respectively, and the annual mean rainfall is $1,748 \mathrm{~mm}$ (DHM 1999). The basin is surrounded by the hills composed of metamorphic and metasedimentary rocks (Fig. 1). The northern border of the basin is the Sheopuri Injection Gneiss Zone composed of tourmaline granitic gneiss, banded gneiss, and augen gneiss (Ohta 1973), whereas the metasedimentary rocks of the Phulchauki and Bhimphedi Groups of the Kathmandu Complex (Stöcklin 1980) bound the basin from all other sides. The metasedimentary rocks distributed in NE of the basin comprise phyllite, schist, and metasandstone, whereas those distributed in SE, SW, and NW comprise limestone, slate, phyllite, quartzite, and metasandstone. The fluvio-lacustrine sediments occupy the central portion of the basin (Fig. 1). They are composed of clay, silt, sand, and gravel with some organic-rich clay (Yoshida and Igarashi 1984). The southern margin of the valley is made up of sand and gravel of the Lukundol Formation (Dongol 1985).

The Manahara and Bagmati Rivers are two major drainage systems, which flow southwestwards by joining with many tributaries. The Sali Nadi from NE (Sheopuri Range), and the Hanumante River and Kodku Khola from SE (Fig. 1) join with the Manahara River. On the other hand, the Manahara River itself confluences with the Bagmati River at Sankhamul (location M in Fig. 1). The Dhobi Khola, Bishnumati River, Balkhu Khola, Nakhu Khola, Bosan Khola, and the 


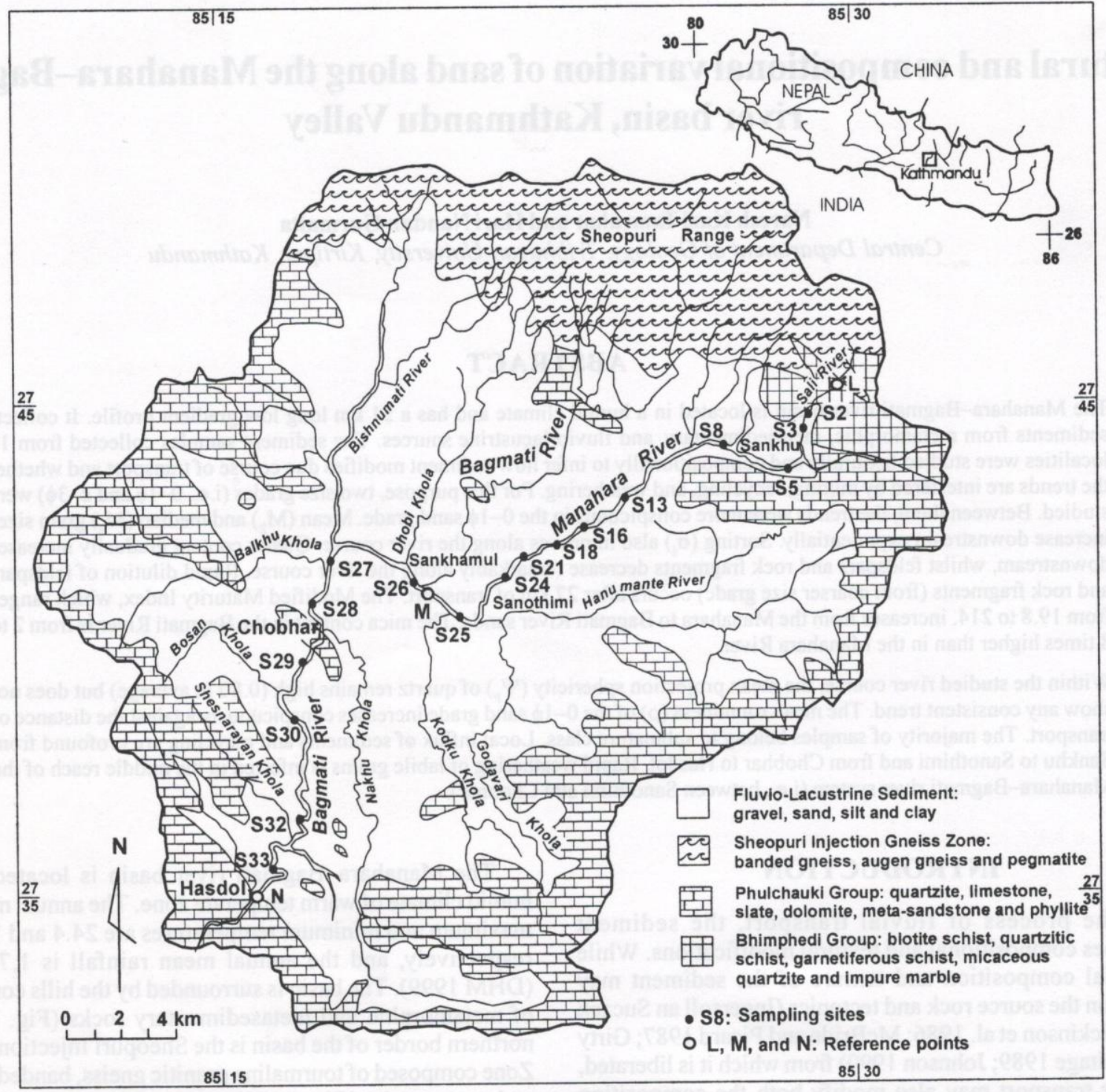

Fig. 1: Generalised geological map of the Kathmandu Basin (based on Stöcklin 1980, and Yoshida and Igarashi 1984) showing location of sample sites and reference points ( $L, M$, and $N$ )

Sheshnarayan Khola join with the Bagmati River from different directions (Fig. 1). The river drains out of the basin from Hasdol and flows further south.

The Manahara River is the fifth-order drainage whereas the Bagmati River is the sixth-order drainage (Bajracharya and Verma 1989). The Manahara River is $26 \mathrm{~km}$ long between Sankhu and Sankhamul, whereas the Bagmati River is $25 \mathrm{~km}$ long between Sankhamul and Hasdol. Therefore, the total length of the Manahara-Bagmati river system is $51 \mathrm{~km}$ (i.e. between $\mathrm{L}$ and $\mathrm{N}$ in Fig. 1 and 2). The average gradient of the Manahara-Bagmati system is about $2.7 \times 10^{-2} \mathrm{~m} / \mathrm{km}$, although a maximum of $29.0 \times 10^{-2} \mathrm{~m} / \mathrm{km}$ (between L and S5) and a minimum of $0.16 \times 10^{-2} \mathrm{~m} / \mathrm{km}$ (from S24 to M, and from S30 to S33, respectively) also exist.

For the purpose of compositional and textural studies, 17 sediment samples of about $400 \mathrm{~g}$ each were collected at an interval of 2-5 km (Fig. 1). They were obtained from the channel, essentially below the flow level. Each of the samples was sieved at an interval of $1 \phi$. Mean grain size $\left(\mathrm{M}_{\mathrm{z}}\right)$, median $\left(\mathrm{M}_{\mathrm{d}}\right)$, sorting $\left(\sigma_{\mathrm{t}}\right)$, degree of symmetry $\left(\mathrm{Sk}_{\mathrm{f}}\right)$, and kurtosis $\left(\mathrm{K}_{\mathrm{G}}\right)$ were determined according to the procedure of Folk and Ward (1957). A classification scheme of Folk and Ward (1957) was also used for interpreting the graphic measures.

Two size grades of $0-1 \phi$ (hereafter referred to as $1 \phi$ ) and $2-3 \phi$ (hereafter referred to as $3 \phi$ ) obtained after the sieve analysis of samples were taken for the compositional study of sand. From each fraction, 600 grains were counted using conventional method (e.g., Johnson 1990), categorising the grains into quartz, feldspar, rock fragments, micas, heavy minerals, and other grains. The rock fragments in this count included phaneritic crystalline grains and aphanitic metasedimentary grains. 


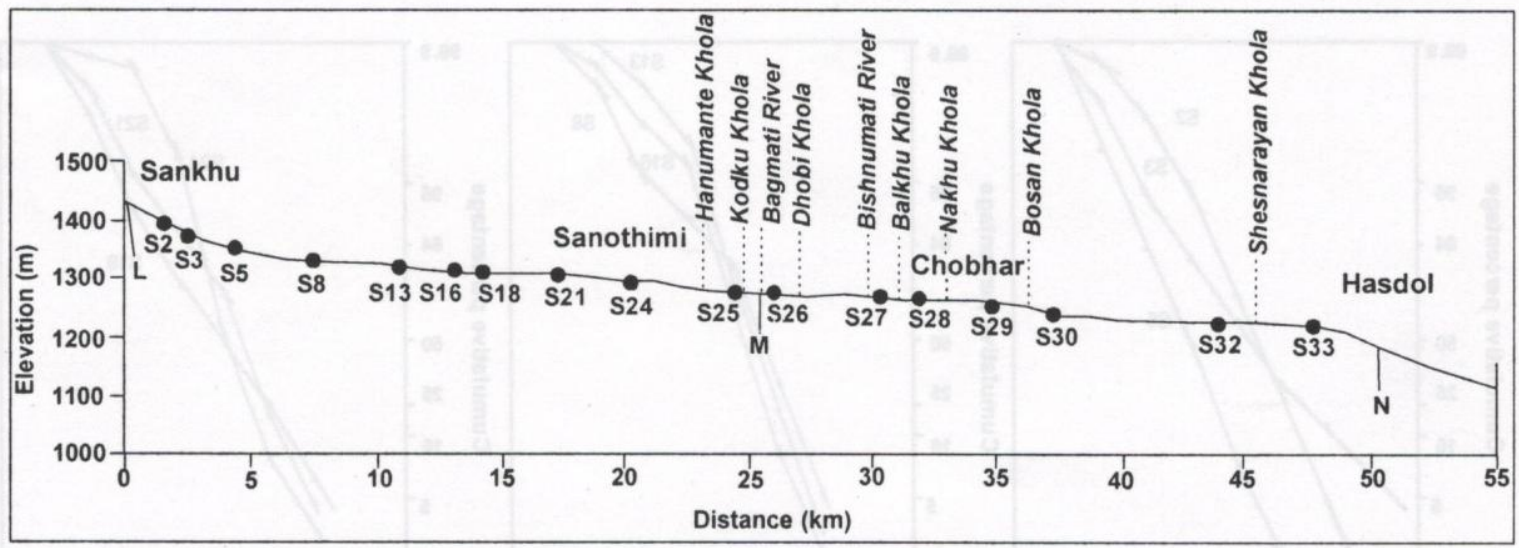

Fig. 2: Longitudinal profile of the Manahara and Bagmati Rivers

For each of the $1 \phi$ and $3 \phi$ sand, about 100 quartz grains were separated and studied for roundness and sphericity. Powers' (1953) roundness chart was used to compare the outlines of quartz to determine roundness values (logarithmic rho scale) of Folk (1955). For determining the projection sphericity, Rittenhouse's (1943) chart was used.

Frequencies in roundness classes of two size grades of each sample were tested statistically to see if there existed any significant difference in roundness between two size grades. The following test statistics was used (Lindholm 1987):

$$
\text { Chi - squared }=\frac{\sum\left(O_{f}-E_{f}\right)^{2}}{E_{f}}
$$

where $O_{f}$ is the observed frequency and $E_{f}$ is the expected frequency.

\section{DOWNSTREAM VARIATION TRENDS OF GRAIN-SIZE PARAMETERS}

The probability plots of samples are arranged from upstream to downstream (Fig. 3). The suspended load is quite low $(<2 \%)$ in most of the Manahara River sand. It approaches between 3 and $5 \%$ in the Bagmati River sand (S32 and S33). On the other hand, the bed load population constitutes relatively coarser size grades in the Manahara River, whereas it is relatively finer in the downstream portion of the Bagmati River.

Graphic measures are listed in Table 1 , where $M_{2}$ and $M_{d}$ range from $-0.58 \phi$ to $2.65 \phi$ and from $-0.6 \phi$ to $2.6 \phi$, respectively. Much of the Manahara River sand is coarsegrained, whereas that of the Bagmati River is fine-grained. Their sorting varies from $0.45 \phi$ (well sorted) to $1.68 \phi$ (poorly sorted). It is observed that the Bagmati River sand is better sorted than the Manahara River sand (Table 1 and Fig. 3).

Skewness ranges from -0.29 (coarse-skewed) to 0.33 (very fine-skewed). The Manahara River sand (L to M; Fig. 2) ranges from coarse-skewed to near-symmetrical types, but much of the Bagmati River sand is fine-skewed. The value of $\mathrm{K}_{\mathrm{G}}$ (Table 1) varies from 0.85 (platykurtic) to 1.39 (leptokurtic).

$\mathrm{M}_{\mathrm{z}}$ and $\mathrm{M}_{\mathrm{d}}$ gradually become finer from upstream to downstream (Fig. 4). Though $M_{d}$ fluctuates, it gives a trend of $\mathrm{Y}=0.6 \mathrm{e}^{0.029 \mathrm{x}}$, where $\mathrm{x}$ is the distance of transport (i.e., the distance from L in Fig. 1) and $\mathrm{Y}$ is $\mathrm{M}_{\mathrm{d}}$. Similarly, the relation between $M_{z}$ and distance is $Y=0.5902 \mathrm{e}^{0.03 x}$, where $\mathrm{Y}$ is $\mathrm{M}_{\mathrm{Z}}$.

The variation trend of sorting against distance of transport is conspicuous. Often, the poorly sorted sand changes to moderately sorted or moderately well sorted type due course of transport (Fig. 4). It has also an exponential trend against distance with a fair, but negative correlation: $\mathrm{Y}=1.1145 \mathrm{e}^{-0.014 \mathrm{X}}$, where $\mathrm{Y}$ is $\sigma_{\mathrm{r}}$. Sorting depends on size range of the available sediment, rate of deposition, and

Table 1: Grain size parameters of fluvial sand from the Manahara and Bagmati Rivers

\begin{tabular}{c|c|c|c|c|c}
\hline Sample & $\mathbf{M}_{\mathbf{d}}(\phi)$ & $\mathbf{M}_{\mathbf{z}}(\phi)$ & $\sigma_{\mathbf{I}}(\phi)$ & $\mathbf{S k}_{\mathbf{I}}$ & $\mathbf{K}_{\mathbf{G}}$ \\
\hline S2 & 0.58 & 0.58 & 0.95 & 0.00 & 1.05 \\
\hline S3 & 2.05 & 2.11 & 0.90 & 0.07 & 1.04 \\
\hline S5 & 0.7 & 0.57 & 1.68 & -0.12 & 1.07 \\
\hline S8 & 0.4 & 0.45 & 1.07 & 0.17 & 1.36 \\
\hline S13 & 0.55 & 0.53 & 0.73 & -0.05 & 1.06 \\
\hline S16 & 0.7 & 0.73 & 0.68 & 0.03 & 1.09 \\
\hline S18 & 1.05 & 1.03 & 1.39 & -0.03 & 0.85 \\
\hline S21 & 0.6 & 0.70 & 1.05 & 0.15 & 1.25 \\
\hline S24 & 0.95 & 0.88 & 0.69 & -0.20 & 1.04 \\
\hline S25 & 1.85 & 1.78 & 0.88 & -0.13 & 0.93 \\
\hline S26 & 2.3 & 2.30 & 0.60 & 0.06 & 1.17 \\
\hline S27 & 1.3 & 1.15 & 0.83 & -0.29 & 1.27 \\
\hline S28 & 0.95 & 1.03 & 0.79 & 0.24 & 1.21 \\
\hline S29 & 1.9 & 2.00 & 0.45 & 0.33 & 1.02 \\
\hline S30 & 1.95 & 2.05 & 0.60 & 0.25 & 1.02 \\
\hline S32 & 2.2 & 2.23 & 0.78 & 0.13 & 1.05 \\
\hline S33 & 2.6 & 2.65 & 0.60 & 0.16 & 1.39 \\
\hline
\end{tabular}



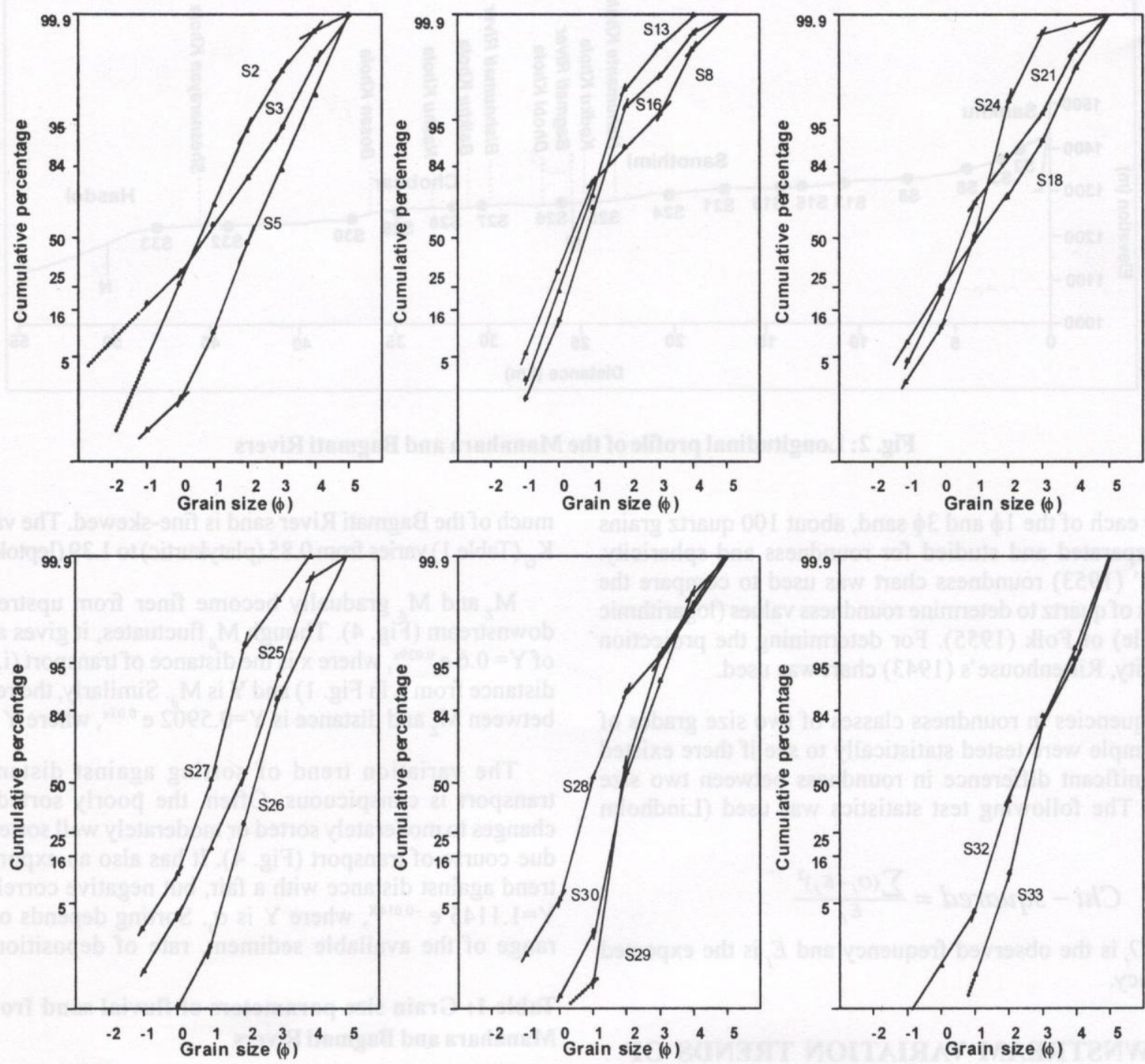

Fig. 3: Probability plots of grain size distribution of fluvial sand from the Manahara and Bagmati Rivers

energy of depositing agent (Amaral and Pryor 1977). Folk (1966) also discussed that generally fine sediments are better sorted. The improvement of sorting against the distance of transport is attributed to hydraulic sorting and contribution of fines from the streams.

The variation in skewness is generally related to the gradient and energy of river (Awasthi 1970). The occurrence of fine-skewed sand (which is also moderately well sorted) in the Bagmati River may be attributed to the addition of fines from the tributaries and removal of coarser grades in the upper reaches due to sorting, mechanical breakdown, and dissolution.

The value of $\mathrm{K}_{\mathrm{G}}$ varies mostly between mesokurtic and leptolurtic. The downstream changes in $\mathrm{SK}_{\mathrm{I}}$ and $\mathrm{K}_{\mathrm{G}}$ are less conspicuous than those of $\sigma_{\mathrm{I}}$ (Fig. 4).

\section{VARIATION TRENDS OF SAND COMPOSITION}

Mineral grain counts of sand are listed in Table 2. The QFL diagram (Fig. 5) shows that much of the $1 \phi$ sand belongs to the lithic type whilst the $3 \phi$ sand ranges from lithic to quartzose varieties. Therefore, it is inferred that the rock fragments progressively break down to release individual mineral grains. This process leads to the impoverishment of rock fragments and enrichment of clay minerals and alteration products in finer sediments (Breyer and Bart 1978; Ingersoll et al. 1984; Cox and Lowe 1995). The variation trends of quartz, feldspar, rock fragments, and mica exhibit that their abundance is fluctuating (Fig. 6)

\section{Quartz}

The proportion of Quartz (Table 2) in the $1 \phi$ sand is the highest in S29 (68\%) and the lowest in S33 (17\%), whilst in 
Table 2: Mineralogical composition of sand from the Mahanara and Bagmati Rivers

\begin{tabular}{|c|c|c|c|c|c|c|c|c|c|c|c|c|c|c|}
\hline \multirow{2}{*}{$\begin{array}{c}\text { Sample } \\
\text { No. }\end{array}$} & \multirow{2}{*}{$\begin{array}{c}\text { Size } \\
\text { Grade }\end{array}$} & \multicolumn{9}{|c|}{$\%$ Grain } & \multicolumn{3}{|c|}{ QFL\% } & \multirow{2}{*}{ MMI } \\
\hline & & $\mathbf{Q}$ & $\mathbf{F}$ & Lp & Lms & $\mathbf{L}$ & $\mathbf{M}$ & $\mathbf{H}$ & $\mathbf{C}$ & $\mathbf{O}$ & $\mathbf{Q}$ & $\mathbf{F}$ & $\mathbf{L}$ & \\
\hline \multirow{2}{*}{ S2 } & $<1 \phi$ & 38 & 21 & 21 & - & 21 & 18 & 2 & - & - & 48 & 26 & 26 & 61.3 \\
\hline & $<3 \phi$ & 49 & 14 & 11 & - & 11 & 15 & 10 & - & - & 66 & 19 & 15 & 97.2 \\
\hline \multirow{2}{*}{ S3 } & $<1 \phi$ & 30 & 10 & 30 & - & 30 & 29 & 1 & - & - & 43 & 14 & 43 & 42.9 \\
\hline & $<3 \phi$ & 57 & 11 & 7 & - & 7 & 22 & 3 & - & - & 76 & 15 & 9 & 134 \\
\hline \multirow{2}{*}{ S5 } & $<1 \phi$ & 20 & 15 & 39 & - & 39 & 24 & 2 & - & - & 28 & 20 & 52 & 25.6 \\
\hline & $<3 \phi$ & 47 & 10 & 24 & - & 24 & 16 & 3 & - & - & 58 & 12 & 30 & 88.7 \\
\hline \multirow{2}{*}{ S8 } & $<1 \phi$ & 33 & 16 & 38 & - & 38 & 12 & 1 & - & - & 38 & 18 & 44 & 49.3 \\
\hline & $<3 \phi$ & 45 & 11 & 24 & - & 24 & 18 & 1 & - & 1 & 56 & 14 & 30 & 81.8 \\
\hline \multirow{2}{*}{$\mathrm{S} 13$} & $<1 \phi$ & 24 & 19 & 38 & - & 38 & 17 & 1 & - & - & 30 & 24 & 47 & 31.6 \\
\hline & $<3 \phi$ & 44 & 7 & 23 & - & 23 & 21 & 4 & - & 1 & 59 & 9 & 31 & 78.6 \\
\hline \multirow{2}{*}{ S16 } & $<1 \phi$ & 22 & 24 & 46 & - & 46 & 8 & 0 & - & & 24 & 26 & 50 & 28.2 \\
\hline & $<3 \phi$ & 54 & 3 & 4 & - & 4 & 37 & 1 & 1 & 1 & 89 & 5 & 7 & 117 \\
\hline \multirow{2}{*}{$\mathrm{S} 18$} & $<1 \phi$ & 30 & 7 & 39 & - & 43 & 20 & 1 & 1 & 1 & 38 & 8 & 54 & 42.9 \\
\hline & $<3 \phi$ & 51 & 15 & 20 & - & 20 & 14 & 1 & 1 & - & 59 & 18 & 23 & 102 \\
\hline \multirow{2}{*}{$\mathrm{S} 21$} & $<1 \phi$ & 35 & 16 & 36 & - & 36 & 11 & 0 & 2 & - & 40 & 18 & 41 & 53.1 \\
\hline & $<3 \phi$ & 50 & 13 & 13 & - & 13 & 24 & 1 & - & - & 67 & 17 & 17 & 100 \\
\hline \multirow{2}{*}{ S24 } & $<1 \phi$ & 41 & 18 & 31 & - & 31 & 9 & 1 & - & - & 45 & 20 & 35 & 68.1 \\
\hline & $<3 \phi$ & 37 & 19 & 37 & - & 37 & 6 & 1 & - & 1 & 40 & 20 & 40 & 57.5 \\
\hline \multirow{2}{*}{$\mathrm{S} 25$} & $<1 \phi$ & 34 & 8 & 35 & 1 & 35 & 20 & 1 & 3 & 1 & 44 & 10 & 46 & 50.4 \\
\hline & $<3 \phi$ & 39 & 22 & 28 & - & 28 & 9 & 2 & - & 1 & 44 & 25 & 32 & 62.6 \\
\hline \multirow{2}{*}{$\mathrm{S} 26$} & $<1 \phi$ & 20 & 1 & 5 & - & 5 & 73 & 1 & - & 1 & 78 & 4 & 18 & 25.0 \\
\hline & $<3 \phi$ & 42 & 16 & 29 & - & 29 & 10 & 3 & - & 1 & 49 & 18 & 34 & 72.4 \\
\hline \multirow{2}{*}{ S27 } & $<1 \phi$ & 37 & 4 & 21 & 1 & 22 & 35 & - & 2 & 1 & 59 & 6 & 34 & 58.7 \\
\hline & $<3 \phi$ & 53 & 16 & 24 & - & 24 & 4 & 4 & - & - & 57 & 17 & 26 & 113 \\
\hline \multirow{2}{*}{$\mathrm{S} 28$} & $<1 \phi$ & 49 & 12 & 24 & - & 24 & 12 & 1 & 2 & 1 & 58 & 14 & 28 & 96.1 \\
\hline & $<3 \phi$ & 60 & 6 & 4 & 1 & 5 & 24 & 5 & 1 & 1 & 85 & 8 & 7 & 147 \\
\hline \multirow{2}{*}{ S29 } & $<1 \phi$ & 68 & 2 & 21 & 1 & 22 & 5 & 2 & 1 & - & 74 & 2 & 24 & 214 \\
\hline & $<3 \phi$ & 47 & 9 & 30 & - & 30 & 12 & 1 & 2 & - & 55 & 11 & 34 & 88.7 \\
\hline \multirow{2}{*}{$\mathrm{S} 30$} & $<1 \phi$ & 25 & 4 & 10 & 1 & 11 & 59 & 1 & 1 & 1 & 63 & 9 & 28 & 33.3 \\
\hline & $<3 \phi$ & 46 & 15 & 18 & - & 18 & 19 & 2 & 1 & 1 & 58 & 19 & 23 & 83.5 \\
\hline \multirow{2}{*}{$\mathrm{S} 32$} & $<1 \phi$ & 24 & 1 & 11 & 18 & 29 & 43 & 1 & 2 & 2 & 45 & 1 & 54 & 30.7 \\
\hline & $<3 \phi$ & 33 & 3 & 22 & 17 & 39 & 24 & 1 & 1 & 1 & 44 & 4 & 52 & 49.3 \\
\hline \multirow{2}{*}{ S33 } & $<1 \phi$ & 17 & 2 & 5 & 5 & 9 & 69 & 1 & 1 & 1 & 60 & 5 & 34 & 19.8 \\
\hline & $<3 \phi$ & 55 & 14 & 1 & - & 1 & 26 & 2 & 2 & 1 & 79 & 20 & 1 & 122 \\
\hline
\end{tabular}

$\mathrm{Q}=$ quartz; $\mathrm{F}=$ feldspar; $\mathrm{Lp}=$ phaneritic igneous (plutonic and hypabyssal) and metamorphic (gneiss) rock fragments; $\mathrm{Lms}=$ metasedimentary rock fragments; $\mathrm{L}=\mathrm{Lp}+\mathrm{Lsm} ; \mathrm{M}=$ mica; $\mathrm{H}=$ heavy mineral; $\mathrm{C}=$ carbonate; $\mathrm{O}=$ other $($ undifferentiated grain, organic component, brick fragment); $\mathrm{QFL} \% \mathrm{Q}=$ recalculated quartz, $\mathrm{QFL} \% \mathrm{~F}=$ recalculated feldspar and $\mathrm{QFL} \% \mathrm{RF}=$ recalculated rock fragments; $\mathrm{MMI}=$ Mineralogical Maturity Index

the $3 \phi$ sand it is the highest in S28 (60\%) and the lowest in $\mathrm{S} 32(33 \%)$. An abundance of quartz remains higher in most of the $3 \phi$ sand (Fig. 6).

\section{Feldspar}

Feldspar is abundant in the $1 \phi$ size grade of the Manahara River sand whereas it is less abundant in the Bagmati River sand (Fig. 6). Along the Bagmati River, the sand shows a decrease in proportion of feldspar to $5-24 \%$ (in the $1 \phi$ sand) and $1-30 \%$ (in the $3 \phi$ sand). Therefore, it remarkably diminishes from the Manahara River to the Bagmati River as the distance of transport increases. Feldspar observed there is corroded showing rough surface. According to Cox and Lowe (1995), labile grains weather and reduce in size faster than quartz. Suttner and Dutta (1986) also discussed that the polymineralic rock fragments and feldspars diminish preferentially to solution during the weathering process. In a humid climate, feldspars and rock fragments are prone to weathering (Suttner and Dutta 1986). We consider that the decrease in feldspar content in the $1 \phi$ sand against the distance of transport may be related to the faster weathering rate of feldspar. 

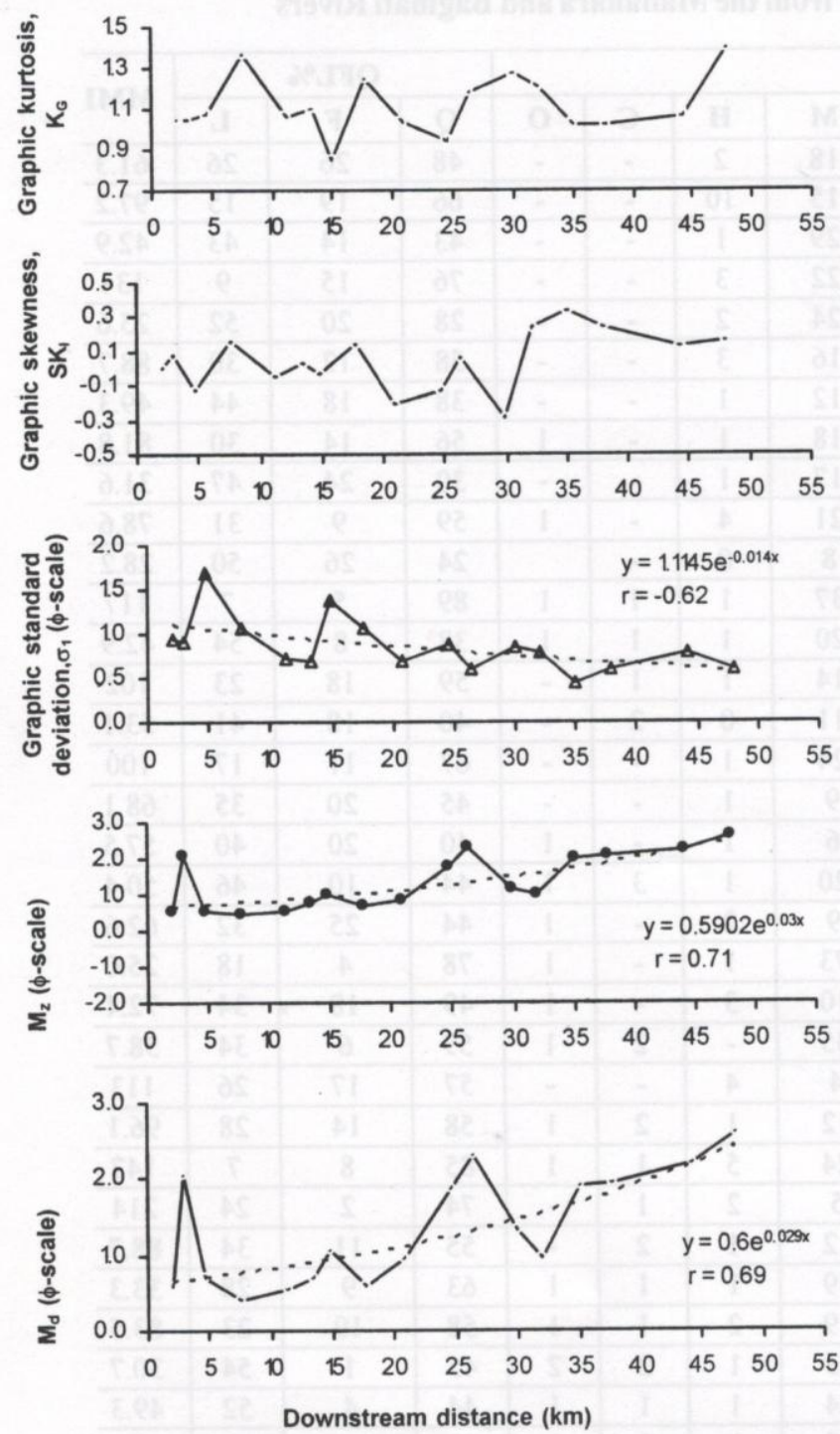

Fig. 4: Downstream variation trend of graphic measures

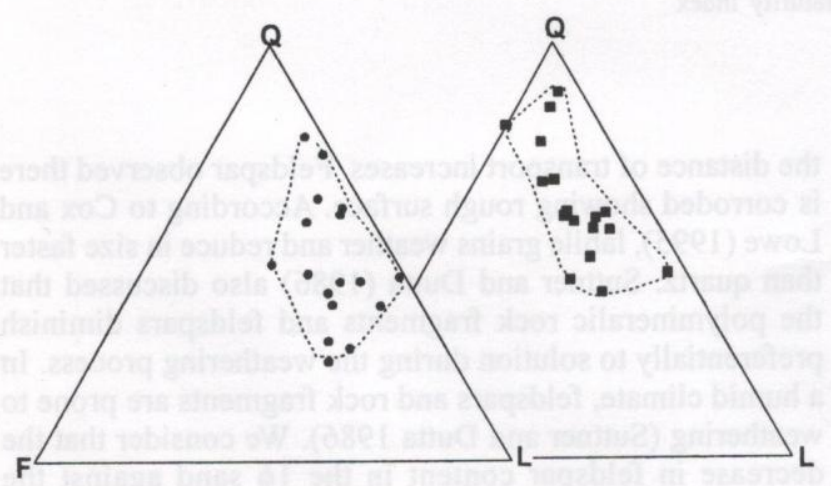

Fig. 5: QFL plots of fluvial sand: (a) $1 \phi$ sand and (b) $3 \phi$ sand
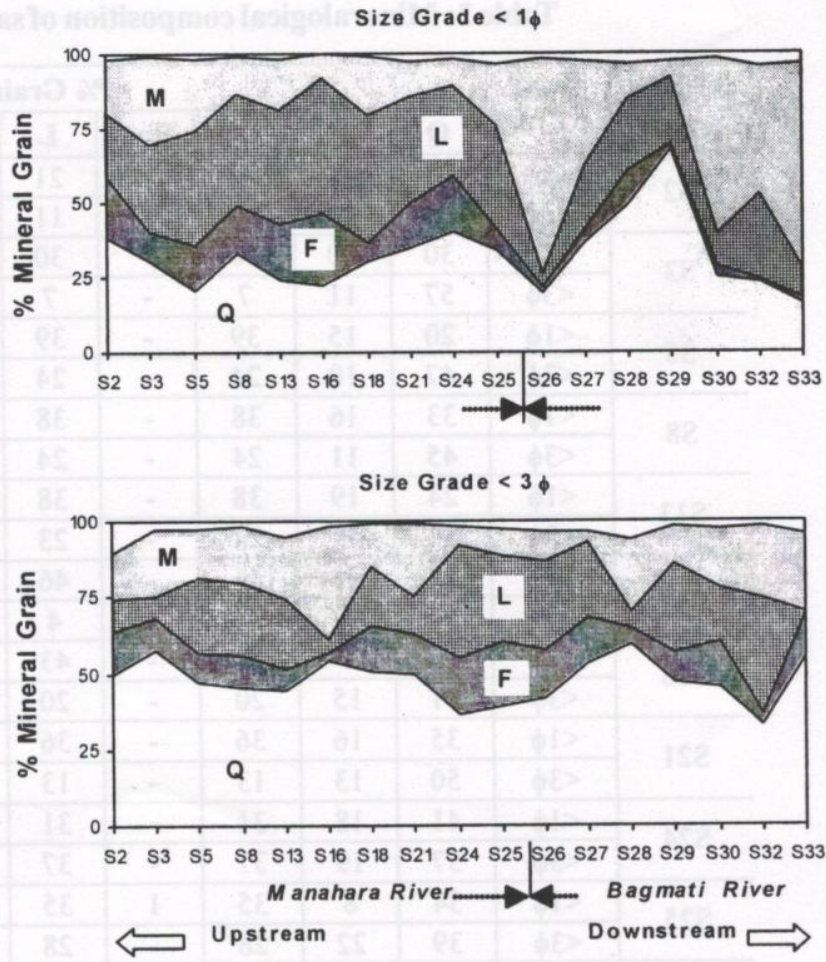

Fig. 6: Downstream changes of percentage of mineral grains and composition of fluvial sand

\section{Rock fragments}

Rock fragments comprise gneissic and granitic grains (Table 2) showing crystalline texture, and aphanitic metasedimentary rock fragments of phyllite, slate, and limestone. In the $1 \phi$ sand, the total rock fragment content is higher (i.e., $21-46 \%$ ) in the Manahara River (from $\mathrm{K}$ to $\mathrm{L}$ in Fig. 2) than in the Bagmati River where it varies from 5 to $29 \%$ (Table 2). The relative abundance of rock fragments (especially, gneissic and granitic grains) in the Manahara River is attributed to the nearness and higher relief of the source rock (i.e. the Sheopuri Injection Gneiss Zone) in the north. On the other hand, the amount of total rock fragments is higher (i.e., 18-39\%) in the $3 \phi$ sand of the Bagmati River than that of the Manahara River (i.e., 4-37\%). Its increasing proportion in the finer size grade in the lower reach of the Bagmati River may be explained by the influx of abundant metasedimentary rock fragments (i.e., the aphanitic grains) from the bedrock located at a distance, and also reworking of the phaneritic rock fragments from the upper reaches as well as from the surrounding fluvio-lacustrine deposits.

\section{Mica}

The abundance of muscovite remains higher in the downstream of the Bagmati River, whereas biotite alters often to chlorite in almost every sample. The total mica content is high in S26 where it reaches to $73 \%$ of the modal composition of $1 \phi$ sand (Table 2). Except for the reach between S8 and S24, mica-content often exceeds $20 \%$. In the $3 \phi$ sand, mica often varies from 14 to $37 \%$ and remains low in the reach 
between S24 and S27. Hence, the mica-content is higher in the coarser size grade and it increases in the sand from the Manahara to the Bagmati Rivers (Fig. 6).

\section{Heavy mineral, calcite, and other grains}

Heavy minerals constitute tourmaline, rutile, garnet, and iron oxides. They vary from 0 to $10 \%$ in overall size grades, and occur in every sample. They remain higher in the finer size grade. Calcite varies from 0 to $3 \%$ and other grains that compose organic debris, brick fragments, and undifferentiated grains vary from 0 to $2 \%$ (Table 2 ).

\section{Modified Maturity Index (MMI)}

McBride and Picard's (1987) Modified Maturity Index (MMI) is defined as:

$$
M M I=\frac{\text { Quart } z+\text { Chert }}{\text { Other clasts }} \times 100
$$

MMI (Table 2) ranges from 19.8 to $214 \%$ in the $1 \phi$ sand and from 49.3 to $147 \%$ in the $3 \phi$ sand. It is fluctuating in the $3 \phi$ sand, whereas there is a marked peak at S29 in the $1 \phi$ sand (Fig. 7). If we consider the trend of $1 \phi$ sand from the sites S2 to S29, MMI increases linearly as a function of the distance of transport with the relationship: $\mathrm{Y}=2.5124 \mathrm{X}+$ 16.881 , where $\mathrm{X}$ is the distance of transport and $\mathrm{Y}$ is MMI. The correlation coefficient $(r)$ for this relation is +0.58 , significant at 0.01 probability level. Further downstream of Chobhar, MMI decreases drastically due to the mixing of sand with the rock fragments and mica.

Table 3: Mean roundness $(\rho)$ and mean projection sphericity $\left(\psi_{\mathrm{p}}\right)$ of quartz grains

\begin{tabular}{c|c|c|c|c}
\hline \multirow{2}{*}{ Sample } & \multicolumn{2}{|c|}{$\rho$} & \multicolumn{2}{|c}{$\Psi_{\mathrm{p}}$} \\
\cline { 2 - 5 } & \multicolumn{1}{|c|}{$\boldsymbol{\phi} \phi$} & $<\mathbf{3}$ & $<\mathbf{\phi}$ & $<\mathbf{3 \phi}$ \\
\hline S2 & 0.84 & 1.51 & 0.78 & 0.81 \\
S3 & 1.35 & 1.90 & 0.76 & 0.82 \\
S5 & 1.28 & 2.21 & 0.77 & 0.82 \\
S8 & 1.23 & 2.13 & 0.79 & 0.82 \\
S13 & 1.92 & 2.09 & 0.80 & 0.80 \\
S16 & 1.96 & 2.53 & 0.85 & 0.78 \\
S18 & 1.77 & 1.78 & 0.82 & 0.78 \\
S21 & 1.79 & 1.70 & 0.82 & 0.79 \\
S24 & 1.91 & 1.56 & 0.82 & 0.81 \\
S25 & 1.67 & 1.73 & 0.81 & 0.78 \\
S26 & 2.01 & 2.32 & 0.81 & 0.81 \\
S27 & 2.01 & 2.06 & 0.80 & 0.79 \\
S28 & 2.34 & 2.11 & 0.80 & 0.80 \\
S29 & 2.66 & 1.73 & 0.83 & 0.81 \\
S30 & 2.22 & 1.93 & 0.81 & 0.81 \\
S32 & 2.41 & 1.81 & 0.78 & 0.81 \\
S33 & 2.13 & 1.57 & 0.78 & 0.82 \\
Average & 1.85 & 1.92 & 0.80 & 0.80 \\
Standard & & & & \\
Deviation & 0.45 & 0.29 & 0.02 & 0.01 \\
\hline & & &
\end{tabular}

\section{ROUNDNESS AND SPHERICITY TRENDS}

Quartz is the most widely studied grain type among the grains for shape study due to its relative durability to chemical deposition and mechanical breakdown (Pettijohn et al. 1987). Therefore, both roundness and sphericity were estimated for the quartz grains.

The mean roundness $(\rho)$ and mean sphericity $\left(\Psi_{\mathrm{p}}\right)$ values for quartz grains are listed in Table 3. In the $1 \phi$ sand, the mean roundness varies from 0.84 to 2.66 , whereas in the $3 \phi$ sand it varies from 1.51 to 2.53 . It means that the quartz grains are in average subangular in nature. Though the mean roundness varies from very angular to subangular, some rounded grains also exist in almost every sample of two size grades, other than samples S2, S3, S5, S8, S18, S21, and S24 (Table 3).

$\Psi_{\mathrm{p}}$ of quartz varies from 0.76 to 0.85 in the $1 \phi$ sand, and from 0.78 to 0.82 in the $3 \phi$ sand. $\Psi_{\mathrm{P}}$ of both size grades exhibit high sphericity values.

Both the roundness and sphericity change against the distance of transport (Fig. 8). The variation trend of the $1 \phi$ sand shows that the mean roundness increases as the downstream distance increases. There is a significant $(\mathrm{t}=31.03)$ and very good correlation $(\mathrm{r}=+0.9)$ between the mean roundness of the $1 \phi$ sand and the downstream distance: $\mathrm{Y}=0.8287 \mathrm{X}^{0.2771}$, where $\mathrm{X}$ is the distance of transport and $\mathrm{Y}$ is the mean roundness of quartz.

\section{TEXTURAL MATURITY}

To examine the textural maturity (Folk 1980), we used bivariate plots of sorting versus mud content $(\%)$, mean roundness versus sorting, and mean roundness versus mud content (\%) for both the size grades of the samples (Fig. 9). The plots indicate that most of the samples are 'submature' and a few are 'mature'. In Fig. 9, the stippled area shows the field where texturally abnormal sands are supposed to plot. But the samples from the Manahara and the Bagmati Rivers

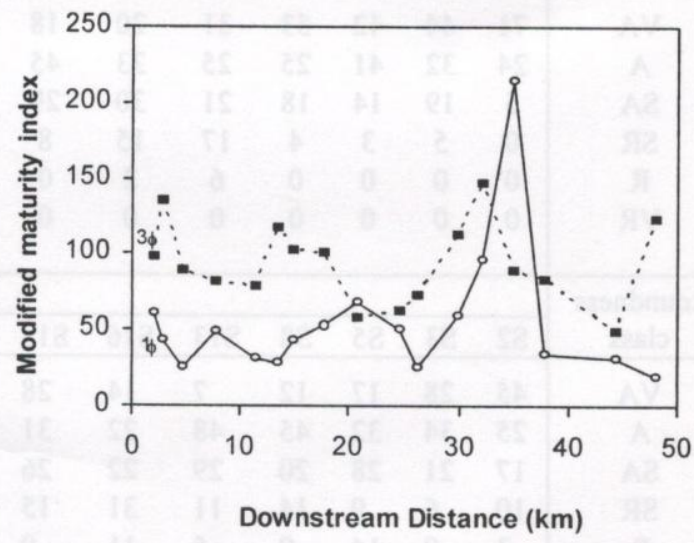

Fig. 7: Downstream changes of mineralogical indices of fluvial sand 

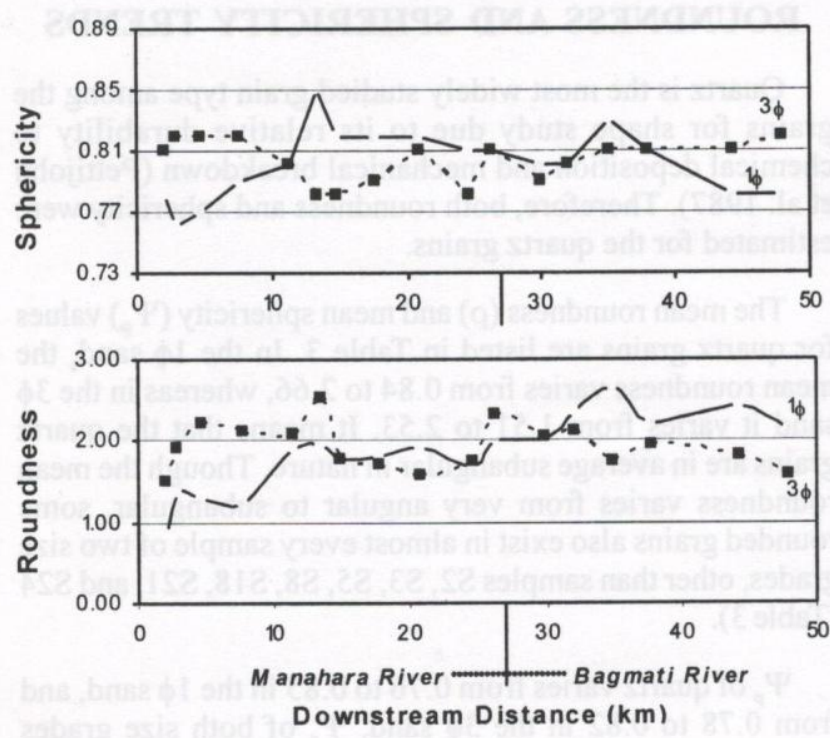

Fig. 8: Plots of roundness and sphericity trends against downstream distance

do not show such an abnormality in terms of mud content, sorting, and roundness. However, it is observed that the samples often showing angular to subangular grains also contain rounded to subrounded grains, and in a few samples well rounded grains (Table 4). Mainly the samples S2, S3, S25, and S26 of the $3 \phi$ sand (Table 4) depict the bimodal distribution of roundness and hence show the textural inversion. Moreover, we further made statistical test (null hypothesis) calculating chi-square values for the roundness of the two size grades for each sample (Table 5) to see whether the difference in $\rho$ values is due to the difference in sources of population. The test results exhibit that $\rho$ in samples S2, S3, S5, S8, S13, and S16 of the Manahara River and samples S28, S29, S30, S32, and S33 of the Bagmati River are statistically different and are significant at the probability level of $0.05\left(\chi^{2}=7.82\right.$ and degree of freedom $=3$ ). However, between the sites S18 and S29 it is not significantly different for both the size grades. The significant results probably suggest the mixing of sediments in the upstream portion of the Manahara River and the downstream portion of the Bagmati River.

Table 5: Chi-square values obtained after comparing roundness of the $1 \phi$ sand and $3 \phi$ sand

\begin{tabular}{c|c}
\hline Sample No. & $\chi^{2}$ \\
\hline S2 & $24.21^{*}$ \\
S3 & $10.26^{*}$ \\
S5 & $31.75^{*}$ \\
S8 & $47.64^{*}$ \\
S13 & $24.94^{*}$ \\
S16 & $15.08^{*}$ \\
S18 & 7.05 \\
S21 & 5.56 \\
S24 & 7.30 \\
S25 & 1.22 \\
S26 & 5.60 \\
S27 & 7.68 \\
S28 & $10.32^{*}$ \\
S29 & $24.97^{*}$ \\
S30 & $14.40^{*}$ \\
S32 & $23.16^{*}$ \\
S33 & $13.88^{*}$ \\
\hline$\chi^{2}=7.82 ;$ degree of freedom $=3 ;$ \\
${ }^{*} \rho=0.05$
\end{tabular}

Table 4: Mean roundness obtained for medium $(1 \phi)$ and fine $(3 \phi)$ sand samples showing roundness distribution and textural abnormality (poor sorting of roundness)

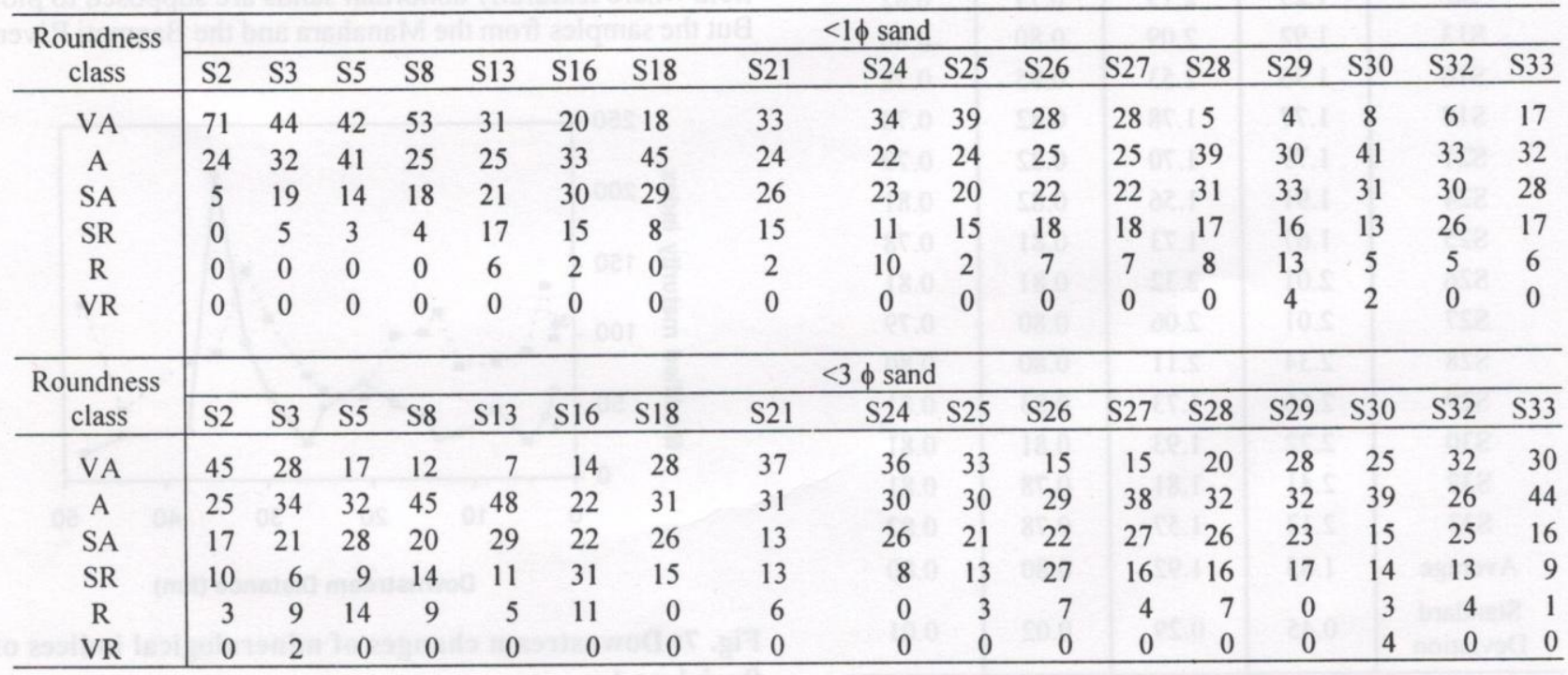



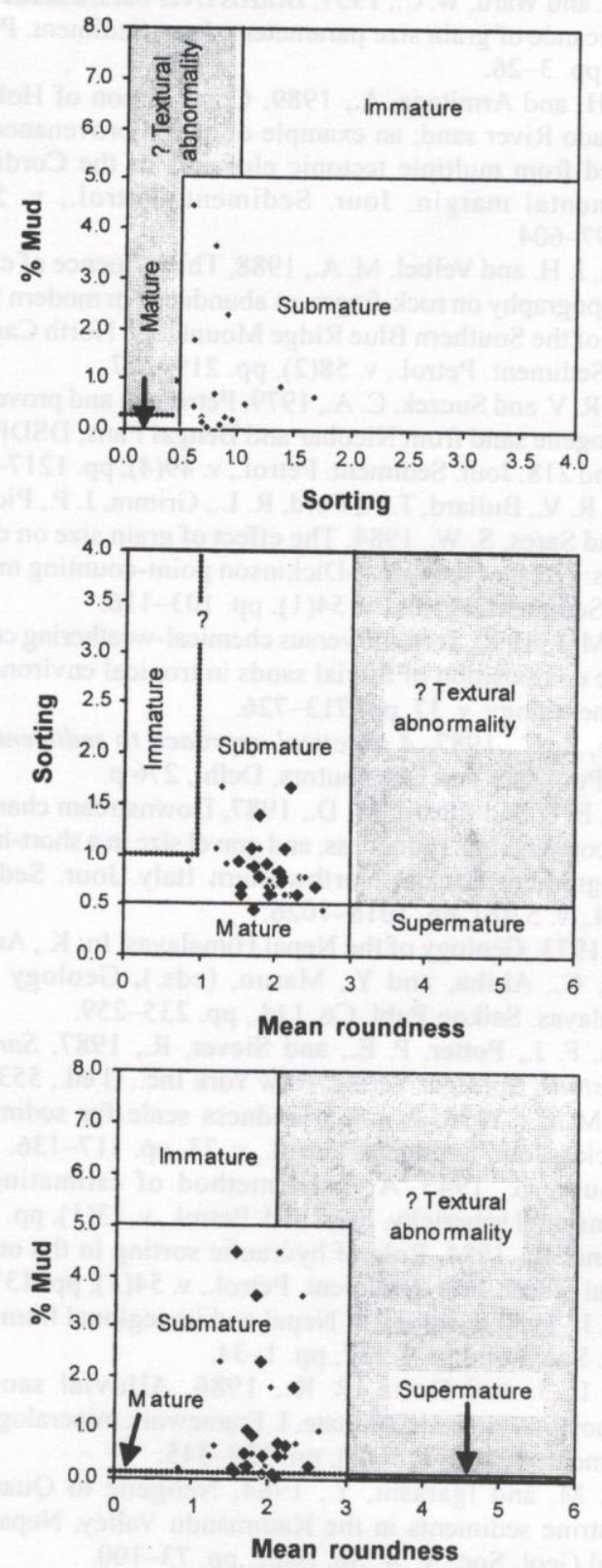

Fig. 9: Bivariate plots of mean roundness versus mud (\%), mean roundness versus sorting, and sorting versus mud (\%) showing most of the plots over the submature field. Solid boundaries (arbitrary boundaries) and dashed boundaries (not clearly defined) are based on Folk (1980). Stippled areas belong to the fields of textural abnormality.

\section{CONCLUSIONS}

Mean and median grain sizes of sand decrease from the Manahara to Bagmati Rivers. Sorting improves more conspicuously than other statistical parameters along the river profile. The skewness also changes from coarse-skewed to fine-skewed from the Manahara River to the Bagmati River, respectively showing the enrichment of fines in the lower reach. There is a tendency of mesokurtic to leptokurtic and fine-skewed sands to be better sorted. It indicates that the finer sediments were brought into the Bagmati River by its tributaries (i.e., the Bosan Khola, Nakhu Khola, and Sheshnarayan Khola). However, part of the fines could have also resulted from hydraulic sorting and weathering of coarser grains.

The finer the sand the more quartzose it tends to be, as a result of dissolution of feldspar and breakdown of rock fragments into discrete mineral grains.

The $1 \phi$ sand gives significant mineralogical variation trends along the Manahara-Bagmati River profile. The quartz content increases whereas the amount of feldspar and rock fragments decreases downstream. Rapid dilution of feldspar and rock fragments (from the $1 \phi$ sand) is taking place between Sanothimi and Chobhar after the sediment is transported for more than $27 \mathrm{~km}$ (i. e., from Sankhu). This implies that the sediment was subjected to intense chemical weathering and its labile constituents were rapidly decomposed from the coarser to the finer sand between Sanothimi and Chobhar (a low gradient reach of the Manahara-Bagmati River profile).

On the other hand, the proportion of feldspar and rock fragments (in $3 \phi$ sand) increases in the lower reach of the Bagmati River due to the influx of metasedimentary rock fragments and grains from fluvio-lacustrine sediments as brought by the Nakhu Khola, Bosan Khola, and Sheshnarayan Khola.

The mica content in the Bagmati River sand is from 2 to 8 times higher than that in the Manahara River sand and it increases rapidly in the lower reach of the Bagmati River. It implies that mica came from the Lukundol Formation containing sand and gravel of granitic and gneissic composition.

Within the entire river course, quartz grains often show high sphericity. On the other hand, roundness steadily increases from upstream to downstream in $1 \phi$ quartz. Although, compositional and textural maturities are interfered by local influx and recycle of sediments, the sand remains almost submature due course of transport through the Manahara and Bagmati Rivers.

Roundness of quartz grains indicates that they come from different sources. Between Sankhu and Sanothimi, the Pleistocene fluvio-lacustrine quartz grains add to the firstcycle quartz coming from the Sheopuri Injection Gneiss Zone. Recycling of quartz grains from fluvio-lacustrine deposits as well as their influx from the Nakhu Khola, Bosan Khola, and Sheshnarayan Khola takes place between Chobhar and Hasdol.

\section{ACKNOWLEDGEMENTS}

We are thankful to the Central Department of Geology (CDG), Tribhuvan University, for providing facilities. We 
thank Mr. K. N. Paudel for his assistance while sampling. We are grateful to Dr. M. R. Dhital (CDG) for fruitful discussions. We also thank Mr. S. S. Shrestha (CDG) for his cooperation during the laboratory work.

\section{REFERENCES}

Amaral, E. J. and Pryor, W. A., 1977, Depositional Environment of the St. Peter Sandstone deduced by textural analysis. Jour. Sediment. Petrol., v. 47(1), pp. 32-52.

Awasthi, A. K., 1970, Skewness as an environmental indicator in the Solani River system, Roorkee (India). Sedimentary Geol., v. 4 , pp. $177-183$.

Bajracharya, S. B. and Verma, V. K., 1989, Morphometric Analysis of the Kathmandu Valley. Jour. Nepal Geol. Soc., v. 6, pp. 11-20.

Breyer, J. A. and Bart, H. A., 1978, The composition of fluvial sands in a temperate semiarid region. Jour. Sediment. Petrol., v. 48(4), pp. 1311-1320.

Cavazza, W., Ziff, G. G., Camporesi, C., and Ferretti, C., 1993, Sedimentary recycling in a temperate climate drainage basin (Senio River, north-central Italy): Composition of source rock, soil profiles, and fluvial deposits, In: M. J., Johnson, and A., Basu. (eds.), Processes controlling the composition of clastic sediments, Geol. Soc. of America, Special Paper 284, pp. 247-260.

Cox, R. and Lowe, D. R., 1995, A conceptual review of regionalscale controls on the composition of clastic sediment and the co-evolution of continental blocks and their sedimentary cover. Jour. Sed. Research, v. A65(1), pp. 1-12.

Department of Hydrology and Meteorology (DHM), Ministry of Water Resources, HMG Nepal, 1999, Unpublished monthly climatological record, Kathmandu, HMG.

Dickinson, W. R., Lawton, T. F., and Inman, K. F., 1986, Sandstone detrital modes, central Utah Foreland region: Stratigraphic record of Cretaceous-Paleogene tectonic evolution. Jour. Sediment. Petrol., v. 56(2), pp. 276-293.

Dongol, G. M. S., 1985, Geology of the Kathmandu fluviatile lacustrine sediments in the light of new vertebrate fossil occurrences. Jour. Nepal Geol. Soc., v. 3, pp. 34-43.

Folk, R. L., 1955, Student operator error in determination of roundness, sphericity, and grain size. Jour. Sediment. Petrol., v. 25 , pp. $297-301$.

Folk, R. L., 1966, A review of grain-size parameters. Sedimentology. v. 6, pp. 73-93.

Folk, R. L., 1980, Petrology of Sedimentary rock. Austin, Texas, Hemphill, 182 p.
Folk, R. L. and Ward, W. C., 1957, Brazos river bars, a study in the significance of grain size parameters. Jour. Sediment. Petrol., v. 27 , pp. 3-26.

Girty, G. H. and Armitage, A., 1989, Composition of Holocene Colorado River sand; an example of mixed provenance sand derived from multiple tectonic elements of the Cordilleran continental margin. Jour. Sediment. Petrol., v. 59(4), pp. 597-604.

Grantham, J. H. and Velbel, M. A., 1988, The influence of climate and topography on rock-fragment abundance in modern fluvial sands of the Southern Blue Ridge Mountains, North Carolina. Jour. Sediment. Petrol., v. 58(2), pp. 219-227.

Ingersoll, R. V. and Suczek, C. A., 1979, Petrology and provenance of Neogene sand from Nicobar and Bengal Fans, DSDP sites, 211 and 218. Jour. Sediment. Petrol., v. 49(4), pp. 1217-1228.

Ingersoll, R. V., Bullard, T. F., Ford, R. L., Grimm, J. P., Pickle. J. D., and Sares, S. W., 1984, The effect of grain size on detrital modes: A test of the Gazzi-Dickinson point-counting method. Jour. Sediment. Petrol., v. 54(1), pp. 103-116.

Johnson, M. J., 1990, Tectonic versus chemical-weathering controls on the composition of fluvial sands in tropical environments. Sedimentology, v. 37, pp. 713-726.

Lindholm, R. C., 1987, A practical approach to sedimentology. CBS Publisher and Distributors, Delhi, $276 \mathrm{p}$.

McBride, E. F. and Picard, M. D., 1987, Downstream changes in sand composition, roundness, and gravel size in a short-headed, high-gradient stream, Northwestern Italy. Jour. Sediment. Petrol., v. 57(6), pp. 1018-1026.

Ohta, Y., 1973, Geology of the Nepal Himalayas, In: K., Arita, Y., Ohta, C., Akiba, and Y., Maruo, (eds.), Geology of the Himalayas. Saikon Publ. Co. Ltd., pp. 235-259.

Pettijohn, F. J., Potter, P. E., and Siever, R., 1987, Sand and Sandstone. Springer Verlag, New York Inc., II ed., 553 p.

Powers, M. C., 1953, A new roundness scale for sedimentary particles. Jour. Sediment. Petrol., v. 23, pp. 117-136.

Rittenhouse, G., 1943, A visual method of estimating twodimensional sphericity. Jour. Sed. Petrol., v. 13(1), pp. 79-81.

Slingerland, R., 1984, Role of hydraulic sorting in the origin of fluvial placer. Jour. Sediment. Petrol., v. 54(1), pp. 137-150.

Stöcklin, J., 1980, Geology of Nepal and its regional frame. Jour. Geol. Soc. London, v. 137, pp. 1-34.

Suttner, L. J. and Dutta, P. K., 1986, Alluvial sandstone composition and paleoclimate, I. Framework mineralogy. Jour. Sediment. Petrol., v. 56(3), pp. 329-345.

Yoshida, M. and Igarashi, Y., 1984, Neogene to Quaternary lacustrine sediments in the Kathmandu Valley, Nepal. Jour. Nepal Geol. Soc., v. 4, Sp. Issue, pp. 73-100. 